\title{
Research
}

\section{Self-Organized Governance Networks for Ecosystem Management: Who Is Accountable?}

\author{
Thomas Hahn $^{1}$
}

\begin{abstract}
Governance networks play an increasingly important role in ecosystem management. The collaboration within these governance networks can be formalized or informal, top-down or bottom-up, and designed or self-organized. Informal self-organized governance networks may increase legitimacy if a variety of stakeholders are involved, but at the same time, accountability becomes blurred when decisions are taken. Basically, democratic accountability refers to ways in which citizens can control their government and the mechanisms for doing so. Scholars in ecosystem management are generally positive to policy/ governance networks and emphasize its potential for enhancing social learning, adaptability, and resilience in social-ecological systems. Political scientists, on the other hand, have emphasized the risk that the public interest may be threatened by governance networks. I describe and analyze the multilevel governance network of Kristianstads Vattenrike Biosphere Reserve (KVBR) in Southern Sweden, with the aim of understanding whether and how accountability is secured in the governance network and its relation to representative democracy. The analysis suggests that the governance network of KVBR complements representative democracy. It deals mainly with "low politics"; the learning and policy directions are developed in the governance network, but the decisions are embedded in representative democratic structures. Because several organizations and agencies co-own the process and are committed to the outcomes, there is a shared or extended accountability. A recent large investment in KVBR caused a major crisis at the municipal level, fueled by the financial crisis. The higher levels of the governance network, however, served as a social memory and enhanced resilience of the present biosphere development trajectory. For self-organized networks, legitimacy is the bridge between adaptability and accountability; accountability is secured as long as the adaptive governance network performs well, i.e., is perceived as legitimate. Governing and ensuring accountability of governance networks, without hampering their flexibility, adaptability, and innovativeness, represents a new challenge for the modern state.
\end{abstract}

Key Words: adaptive capacity; adaptive cycle; adaptive governance; bridging organizations; ecosystem service; informal institutions; leadership; naturum; panarchy; path dependency

\section{INTRODUCTION}

In a representative democracy, the central arena of democratic accountability is the political assembly, the elected representatives. In principle, accountability measures should allow citizens to monitor the exercise of public authority in all policy arenas. Accountability refers to the capacity of citizens to keep in check those who possess public authority through procedures "compelling these officeholders to give reasons for their actions and, when performance is deemed unsatisfactory, to sanction them by media-enabled protest, legal challenges or, more routinely, the withdrawal of electoral support for the governing party" (Mason 2005:3). Democratic political accountability is typically tied to the sovereign authority of nation states. Trends in governance, however, are diluting the authority of nation states by decentralization of power to local authorities or centralization to global and regional institutions. Horizontal reallocation of power includes public-private partnerships, privatization and corporate social responsibility (i.e., the market), as well as voluntary organizations and increased public participation (i.e., the civil society) (Hooghe and Marks 2003). 
In the development field, the growing role of corporations and not-for-profit nongovernmental organizations (NGOs) in delivering public goods and services in multiple and overlapping jurisdiction has heightened the indeterminacy of political accountability (Mason 2005). In the environmental field, accountability issues have been addressed mainly at the global level (Young 2002, Gulbrandsen 2004, Biermann 2007). The relation between legitimacy and accountability seems to be scale-dependent. Although distinguished conceptually, the challenges of legitimacy and accountability are often treated as similar in international governance (Biermann 2007), whereas in local governance, they are obviously different. Informal self-organized governance networks may increase legitimacy if a variety of stakeholders are involved, but at the same time, accountability becomes blurred when decisions are made (Stoker 1998).

I focus on the tension between the observed effectiveness of governance networks, especially self-organized networks, and accountability of representative democracy. Drawing on Kettl (2000), the key challenge is to promote flexibility, adaptability, and innovation, which are all enabled by self-organized networks, while at the same time maintaining the accountability of elected democratic bodies.

In the literature of ecosystem management, the effectiveness of governance networks is emphasized. The resilience of ecosystems, a cornerstone of sustainable development (Folke 2002), is expected to increase when the knowledge and experiences of different stakeholders are taken into account in management decisions, especially in times of uncertainty and rapid change (Scheffer et al. 2003, Berkes et al. 2003). The social memory (Barthel et al. 2010) embedded in the persons and organizations of the governance network or "shadow network" (Olsson et al. 2006) provides a context for successful adaptation, thereby enhancing the resilience of the social-ecological system (Folke et al. 2005). Hence, these and other scholars in ecosystem management have focused on the enhanced potential of collaboration in governance networks for social learning, innovative responses, and adaptive governance of the complex interactions in socialecological systems (Schusler et al. 2003, Tippett et al. 2005, Lebel et al. 2006, Pahl-Wostl et al. 2007).

Political scientists, on the other hand, have tended to emphasize issues of legitimacy and accountability.
Two potential sources of accountability deficits in self-organized governance networks are (1) the individual constituent elements of the network, i.e., the relation between the individual and the organization s/he represents, and (2) those excluded from the network (Stoker 1998). The first is an internal accountability issue for the participating organization (are the persons representing their organization or just themselves?), whereas the latter becomes a legitimacy and accountability problem for the larger context if important stakeholders are excluded directly or lack resources for participation. The governance trend in the western world is that civil society increases its influence at the expense of elected representatives of the state (Ansell and Gash 2007), and this may have adverse effects on the balance of power in society if nobody represents the interest of politically and economically weak stakeholders.

There is limited and contrasting empirical evidence about the relationship between representative democracy and governance networks, resulting in a polarized debate (Klijn and Skelcher 2007). For example, Hajer and Wagenaar (2003) support the more optimistic findings of the ecosystem management scholars and emphasize flexibility and adaptability to new concerns through deliberation. As a contrast, Lowndes (2001) sees governance network as giving power, privilege, and structural advantage to some private interests at the expense of the public interest. Such elite capture is not limited to low-income countries. Unpacking various forms of governance networks, Klijn and Skelcher (2007:596) suggest that representative democracy may devolve questions of "low politics," such as managerial issues to governance networks, as a way to combine traditional accountability with deliberations in stakeholder networks.

Citizen is a broader concept than stakeholder, and the general public may not have the same interests as the stakeholder groups that dominate the governance networks. As continuous degradation of ecosystem services affects human well-being (Millennium Ecosystem Assessment 2005) and potential management failure may harm the general public, it becomes more important that governance networks, which are often self-organized, are not operating independent of the representative democracy. At the same time, traditional bureaucratic nonadaptive governance systems will also be questioned if they are unable to effectively respond to declining ecosystem services (Holling and Meffe 1996). As the ecological scale of 
management concerns increases, for example, to a catchment or a landscape scale, we generally find a mix of property rights regimes and the need to coordinate management in order to reduce the spillover effects (external costs) among stakeholders, including private landowners, local communities, municipalities and governmental agencies at different levels, and various NGOs. Due to their interdependence, no stakeholder can fulfill its objectives in isolation from actions of other stakeholders (Imperial 2005).

Worldwide, around 200,000 groups have been established since the early 1990 s to collaborate for watershed, forest, irrigation, wildlife, and fishery management (Pretty 2003). Only in the Western United States, more than 100 coalitions of environmentalists, ranchers, county commissioners, federal and state government officials, loggers, skiers, and off-road vehicle enthusiasts are cooperating in an attempt to improve ecosystem management on private and public lands (Steel and Weber 2001:121). Despite this growing role of networks, accountability issues have so far not been the focus of literature; a search for (accountab* ecosystem* network*) at ISI Web of Knowledge renders only one hit.

I highlight the specific type of collaboration most relevant to accountability issues, namely governance networks. A governance network is the web of relationships between government agencies, business, and civil society actors concerning public policy making and implementation. ${ }^{[1}$ Such networks link individuals representing organizations at multiple levels and enable them to navigate the institutional framework for gaining legal, political, and financial support (Hahn et al. 2008).

The case study is the governance network that has emerged for a partial watershed in southern Sweden, Kristianstads Vattenrike Biosphere Reserve (KVBR). This biosphere reserve is a result of a bottom-up initiative that has revolutionized the ecosystem management in the municipality of Kristianstad since the start of 1989 . We have described how the governance network around KVBR has transformed the management to ecosystem-based management (Olsson et al. 2004), how the bridging organization operates (Hahn et al. 2006), and the role of the local steward organizations (Schultz et al. 2007) and social networks (Hahn et al. 2008). Democratic aspects of KVBR have not been examined. I examine the role of the key persons within a self-organized governance network, their mandate within their agency or organization, and the accountability of the whole governance network in relation to the formal political system. The research questions were the following:

1. How can the governance network of KVBR be analyzed in terms of its relation to the representative democratic system?

2. What are the implications for accountability, given that many decisions are taken by the self-organized governance network?

3. Does the governance network contribute to the adaptive capacity of KVBR and resilience of the biosphere trajectory?

4. What are the lessons learned concerning how a municipality can enhance effectiveness, innovativeness, and adaptability without sacrificing accountability?

During the process of writing this paper, an unexpected conflict emerged among the local politicians concerning a uniquely large investment in KVBR called "Naturum." The politicians could no longer passively make the decisions proposed by the governance network. This allowed me to explicitly test the third research question, which otherwise is very difficult to evaluate (Plummer and Armitage 2007). The Results starts with a narrative, addressing the first two research questions. The process of Naturum is also a narrative but is analyzed in a particular framework of adaptive capacity. This is followed by the main analysis of the whole governance network. Finally, possible generalizations are discussed.

\section{METHODS}

Semi-structured open-ended interviews (Kvale 1996), most of them via telephone, were conducted with 23 key persons. Thirteen of these key persons were selected from a list suggested by Magnusson, the director of KVBR. Half of the other 10 were suggested by the interviewees as a form of snowball sample (Biernacki and Waldorf 1981), and the rest were found, in municipal documents, to be involved in decisions concerning KVBR. The majority of the 
respondents did not think of themselves as belonging to a "governance network of KVBR"; they were just doing their job as civil servants. After these interviews, I concluded that the most relevant organizations and key persons had been covered. Interviews were partially transcribed and synthesized into a coherent narrative. Analytical frameworks suggested mainly by Klijn and Skelcher (2007), but also Holling et al. (2002), were employed. When information was inconsistent or incomplete, the respondents were asked to clarify. Newspapers and municipal protocols were used to triangulate crucial facts and results. The respondents who provided the most important information were allowed to read and comment on selected paragraphs. Accountability was assessed both internally (the mandate of the key persons within their organizations) and externally (how political accountability was secured). The following issues were covered in all interviews:

- In what ways have you supported the development of KVBR, e.g., with knowledge input, financially, providing links to other key persons, navigating institutional arrangements, lobbying within or outside your organization?

- Did you have a mandate from your agency/ organization for participating in the KVBR governance network? If so, did you create this mandate yourself?

- Who is accountable if a project you are involved in fails?

- Is the decision-making process for KVBR integrated and nested in the formal democratic structures or has the Biosphere Office and its governance network created a "parallel democracy"?

\section{BACKGROUND: A FLEXIBLE PROJECT ORGANIZATION UNDER THE MUNICIPAL UMBRELLA}

KVBR is the lower Helgeå River catchment in southern Sweden that stretches $35 \mathrm{~km}$ from upstream forests, through agricultural land, wetlands, and the City of Kristianstad to the Hanö Bay, a coastal area of the Baltic Sea. In June 2005,
KVBR became the first UNESCO Man and the Biosphere (MAB) Reserve in Sweden fulfilling the Sevilla requirements of 1995 . The first proposal for a biosphere reserve was presented to the municipal executive board (MEB) in 1989 by a few concerned local inhabitants, including birdwatchers, conservationists, researchers, and a hotel director who was formerly president of the Kristianstad Tourism Board (Olsson et al. 2004). The chair of the MEB was impressed by the broad vision and mobilization (Kristiansson, personal communication), and the MEB agreed to establish a small municipal organization, Ecomuseum Kristianstads Vattenrike. Since the beginning of 1989, Magnusson has been the director of the Ecomuseum, which became the Biosphere Office (BO) in 2005.

The mandate of the Ecomuseum/BO was to initiate collaborative projects achieving synergy effects for conservation and sustainable use of ecosystem services, with the long-term objective of becoming a biosphere reserve. In 2002, the BO received the Conservation Award from the Swedish Species Information Centre (ArtDatabanken) for its "systematic work on integrating the values of the wetlands into the ordinary operations of the municipality."[2]

The $\mathrm{BO}$ is a project organization directly under the Chair of the MEB. The collaboration of the BO can be categorized into three types of groups (Olsson et al. 2007):

- Theme groups

- Adhocracy or issue groups

- The consultancy group for nature conservation

The basic idea behind the successful collaboration is to build trust with strategic stakeholders, identify common interests for collaboration, and initiate projects that promote conservation and sustainable use of ecosystem services. After the initial focus on flooded meadows, other themes for managing and developing dynamic landscapes have emerged, including sandy grasslands, groundwater, coastal sand dunes, etc. Aside from these strategic longterm collaborations, the $\mathrm{BO}$ has initiated small adhocracy projects (i.e., small project groups working on particular issues; see Mintzberg 1979) on cranes, geese, stork, river-pearl mussel, European catfish, and ecotourism projects like the 
riverboat. Theme and adhocracy projects do not concern collective-choice issues; they need not involve government agencies or municipal administrations, rather it is a form of private voluntary collaboration, usually involving private landowners and local NGOs. This explains the focus on consensus and "win-win" projects.

The consultancy group for nature conservation, on the other hand, is a forum for discussing collectivechoice issues like land-use planning. Here, representatives from several municipal administrations, the county administrative board (CAB), farmers organizations, and local nature steward NGOs meet and discuss emerging issues and different proposals, usually from the BO, before decisions are made by the MEB and the local (municipal) parliament. Including some of the local actors of the governance network, the consultancy group is a more conventional form of stakeholder consultation that enhances legitimacy and gives the MEB early signals of change.

\section{RESULTS: THE GOVERNANCE NETWORK OF KVBR AND ITS KEY PERSONS}

The theme and adhocracy groups described above are focused on practical ecosystem management issues; this is what Schultz et al. (2007) call local steward networks. Their primary concern is to generate knowledge and collaborate around welldefined projects. Governance networks, on the other hand, focus primarily on formulating visions and policies, creating meaning/sense-making for these visions, solving conflicts, and developing links to agencies and other organizations for gaining political, legal, and financial support (Hahn et al. 2008). The governance network of KVBR (Fig. 1) has been strategically developed by Magnusson, the director of the BO. Various actors and organizations within this governance network are mobilized to support the local steward networks and appear to offer a social memory of how to respond to ecosystem change (Olsson et al. 2007).

Most key persons I interviewed perceived a clear mandate from within their agency/organization to work with and support KVBR. Indeed, their involvement in KVBR was seen as part of their ordinary job rather than being part of a governance network, hence the major part of the governance network belongs to the conventional political structure. However, some interviewees had created their own mandate, especially the key persons at the
BO (Magnusson, Magntorn), the CAB (Cronert), the Swedish MAB Committee (Olsson), WWF Sweden (Löfroth), and Stockholm University (Folke and others). Unless Olof Olsson had established a national MAB Committee and convinced the Swedish Environmental Protection Agency (SEPA) to support the MAB Programme, Kristianstads Vattenrike would probably not be a biosphere reserve today. Therefore, the governance network is a combination of organizations/agencies and key persons with their own agendas.

At an early stage, Magnusson decided that the MAB Programme was the most suitable socio-political framework for his vision of eco-development. In the mid-1990s, he contacted Olof Olsson, who was the contact person for MAB issues at the Swedish Council for Planning and Coordination of Research (FRN). There was no separate MAB committee in Sweden in the 1990s, and SEPA had no interest or instructions to work with MAB (Olsson, personal communication). Inspired by Magnusson, Olsson convinced his superiors at FRN to develop a MAB committee and asked SEPA, other authorities, and research organizations for representatives. During the initial work in the new committee, the SEPA representative (Zettersten) realized step-by-step the usefulness of biosphere reserves in Sweden. This new insight within the SEPA paved the way so that, in early 2001, Olsson together with Carl Folke at Stockholm University could persuade the director of SEPA to let MAB become one of SEPAs official tools, especially for fulfilling SEPA's new instructions of a better bottom-up approach in their nature conservation work. Throughout this process, Olsson created his own mandate completely. His motivation was his commitment toward Magnusson and the challenge to make Kristianstads Vattenrike the first real Swedish biosphere reserve (Olsson, personal communication).

Another crucial link was to the CAB. Hans Cronert, who helped Magnusson start Kristianstads Vattenrike in 1989, had been responsible for nature conservation and nature reserves at the $\mathrm{CAB}$ since then and was also an active member of the Bird Society of North-Eastern Scania (Olsson et al. 2004). He has been the personal link between the $\mathrm{CAB}$ and the $\mathrm{BO}$ by various arrangements of mixed employments.

Another key person at the CAB was Göran Mattiasson, who entered the process in 1997 and helped formalize the Consultancy Group for Nature 
Fig. 1. The governance network of KVBR. There are links between several of the other nodes as well, but all nodes except Unesco MAB and the Resilience Alliance became involved in the governance network after initial contacts by Magnusson at the BO. The nodes are agencies/organizations, except in five cases (noted by names) in which the nodes could be described as individuals who created their own mandates within their respective organizations.

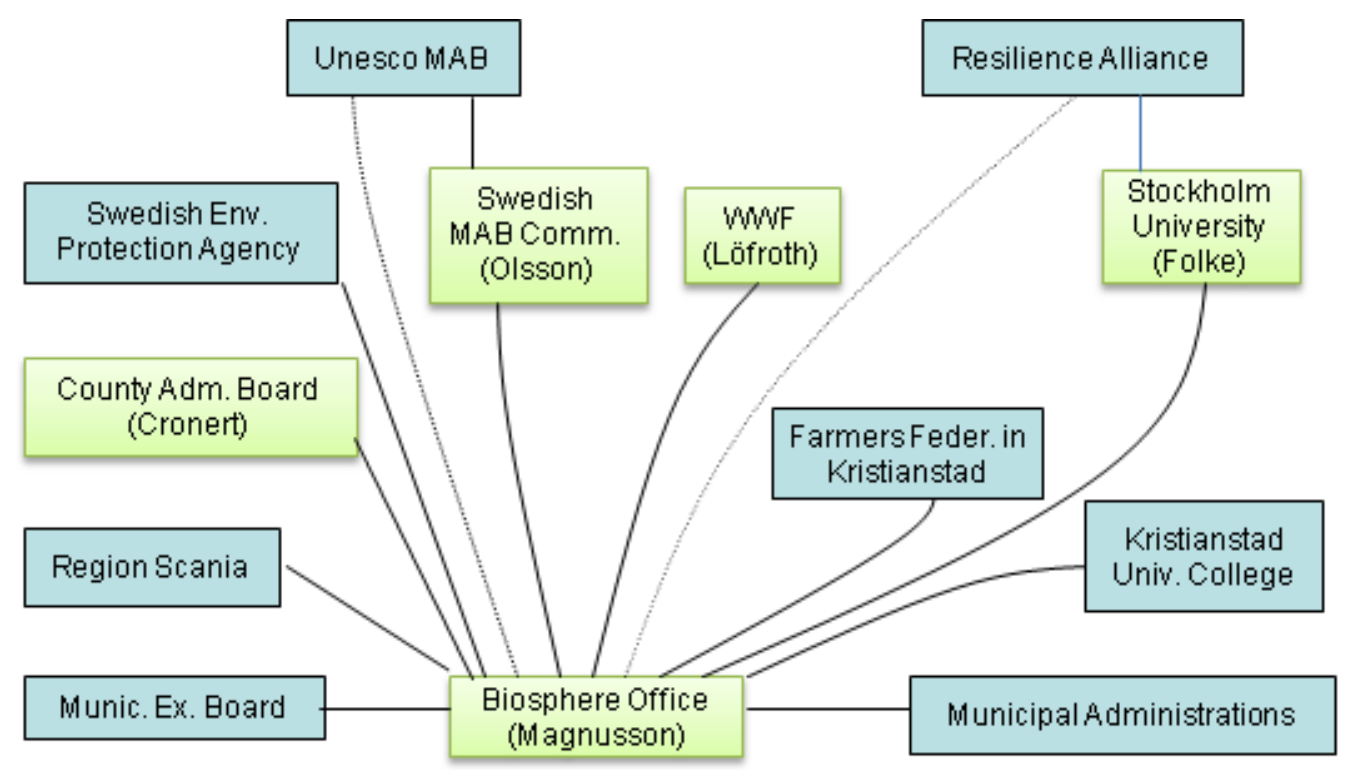

Conservation so that representatives from the municipality and the $\mathrm{CAB}$ were given instructions to participate. Mattiasson also initiated the successful process of three-year plans. These plans for nature conservation, proposed by the $\mathrm{BO}$, are discussed by the Consultancy Group and finally decided upon by the MEB. This institutionalization helped solve a crisis of legitimacy and accountability (Mattiasson, personal communication). Mattiasson also strengthened the link to Torsten Larsson at SEPA, who provided important institutional support.

The key persons of the governance network of KVBR are listed in Table 1, and their roles are also summarized. All key persons perceived the governance network as well integrated, or embedded/nested, in the formal democratic structure, with no sign of "parallel democracy." According to Bo Kristiansson, the former Chair of the MEB:

There has never been any conflicts between the $B O$ and the $M E B$. We have given the $B O$ free hands although formally it is the responsibility of the $M E B$. They have been transparent and I've never felt cheated. The $B O$ has always been fully embedded in the formal democratic decision-making.

From the municipal administrations, the unique status of the $\mathrm{BO}$ was noticed:

When we collaborate with the BO they are just like another municipal administration; they are also under the MEB. But in other cases the BO has managed to include actors from other sectors, tuning down their municipality identity. People respect Magnusson for his engagement and integrity (Theander, personal communication).

City developers like me were afraid that more nature conservation would create a "dead hand" on development. But Magnusson realized that development must continue although in harmony with nature... He managed to convince politicians and 


\section{Table 1. Interviews with key persons of the governance network around KVBR}

\begin{tabular}{|c|c|c|c|}
\hline Organization & $\begin{array}{l}\text { Formal } \\
\text { institution }\end{array}$ & Key person & Description of role \\
\hline Unesco MAB Office & No & Peter Dogsé & $\begin{array}{l}\text { Gave comments on an application draft to check formalities as part of his job. } \\
\text { Was first contacted by Olof Olsson about KVBR. }\end{array}$ \\
\hline $\begin{array}{l}\text { Swedish MAB } \\
\text { Committee }\end{array}$ & No & $\begin{array}{l}\text { Olof Olsson, } \\
\text { secretary }\end{array}$ & $\begin{array}{l}\text { Developing a national MAB committee and influencing/lobbying SEPA to } \\
\text { promote biosphere reserves. Established crucial links between Magnusson (the } \\
\text { BO), Dogsé (Unesco), and Folke (researcher). }\end{array}$ \\
\hline \multirow[t]{3}{*}{ SEPA } & \multirow[t]{3}{*}{ Yes } & Torsten Larsson & $\begin{array}{l}\text { Wetland expert. Convinced SEPA to pay partial salary to one staff member } \\
\text { (Cronert) for some years to develop the wetlands. SEPA has helped with criteria } \\
\text { for listing Nature } 2000 \text { areas in the area and making priorities. }\end{array}$ \\
\hline & & $\begin{array}{l}\text { Gunnar } \\
\text { Zettersten }\end{array}$ & $\begin{array}{l}\text { Member of the Swedish MAB Committee. Financial support to the MAB } \\
\text { Committee and the BO. }\end{array}$ \\
\hline & & Anders Bergqvist & $\begin{array}{l}\text { Works with the building of Naturum, which is a major external investment for } \\
\text { SEPA. }\end{array}$ \\
\hline \multirow[t]{2}{*}{ Region Scania } & \multirow[t]{2}{*}{ Yes } & Bo Fransman & $\begin{array}{l}\text { Environmental fund. Supported KVBR in its application process to become a } \\
\text { biosphere reserve: "The BO is a serious partner and writes good applications." }\end{array}$ \\
\hline & & $\begin{array}{l}\text { Christine } \\
\text { Axelsson }\end{array}$ & $\begin{array}{l}\text { Chair of Regional Development Fund 2002-2006. Decided to support KVBR } \\
\text { financially. }\end{array}$ \\
\hline \multirow[t]{3}{*}{$\mathrm{CAB}$} & \multirow[t]{3}{*}{ Yes } & $\begin{array}{l}\text { Göran } \\
\text { Mattiasson }\end{array}$ & $\begin{array}{l}\text { Helped nesting the local networks into the political structure by formalizing The } \\
\text { Consultancy Group in } 1997 \text {. "Now when it is a biosphere reserve the politicians } \\
\text { need to 'own' the process to be more accountable, the BO cannot remain in } \\
\text { charge of everything." }\end{array}$ \\
\hline & & Elisabeth Hellmo & $\begin{array}{l}\text { Director for Environmental Unit, responsible for nature reserves. Transfers } \\
\text { national grants from SEPA and assists municipality administrations. }\end{array}$ \\
\hline & & Hans Cronert & Has been the personal link between the CAB and the municipality since 1989 . \\
\hline \multirow[t]{3}{*}{ MEB } & \multirow[t]{3}{*}{ Yes } & Bo Kristiansson & $\begin{array}{l}\text { Chair 1988-1991 and 1998-2002. Inaugurated the BO as a municipal } \\
\text { organization. }\end{array}$ \\
\hline & & Heléne Fritzon & $\begin{array}{l}\text { Chair 2002-2006. Has pushed for building the new Centre, Naturum: "Regarding } \\
\text { KVBR, all formal decisions have been taken by the local parliament." }\end{array}$ \\
\hline & & Bengt Gustafson & $\begin{array}{l}\text { Chair since 2006. Continues to support KVBR: "The biosphere reserve fits with } \\
\text { our municipal profile. The present conservative rule makes no difference in this } \\
\text { respect." }\end{array}$ \\
\hline \multirow[t]{4}{*}{$\begin{array}{l}\text { Municipal } \\
\text { administrations }\end{array}$} & \multirow[t]{4}{*}{ Yes } & Ingvar Lövkvist & $\begin{array}{l}\text { Head of Land and Exploitation Office 1985-2006. Managing Municipal Director } \\
2007-2008 \text { when the large investment in Naturum was decided. "Projects have } \\
\text { often started after informal agreements between SEM and the Chair of MEB } \\
\text { before being formal decisions being made, but that's often how it works." }\end{array}$ \\
\hline & & Tomas Theander & $\begin{array}{l}\text { City Architect. Assisted the BO with physical (land use) planning issues and } \\
\text { strategies for climate and transportation: "In this respect there is no difference } \\
\text { compared to collaborating with other municipal administration, they are also } \\
\text { under the MEB." }\end{array}$ \\
\hline & & $\begin{array}{l}\text { Michael } \\
\text { Dahlman }\end{array}$ & $\begin{array}{l}\text { Environmental and Technical Administrations. Helped KVBR with expertise on } \\
\text { water issues. }\end{array}$ \\
\hline & & Göran Persson & $\begin{array}{l}\text { Head of the Coordination Administration. "There is no change in flexibility for } \\
\text { the BO since it became part of the Coordination Administration." }\end{array}$ \\
\hline
\end{tabular}




\begin{tabular}{llll}
\hline BO & No & $\begin{array}{l}\text { Sven-Erik } \\
\text { Magnusson } \\
\text { Karin Magntorn }\end{array}$ & $\begin{array}{l}\text { Director since 1989. Initiated Kristianstads Vattenrike together with Cronert and } \\
\text { others (Olsson et al. 2004). }\end{array}$ \\
Information director and Director of Naturum. Coordinated the MAB application. \\
No
\end{tabular}

civil servants thanks to his knowledge, broad vision and large network (Lövkvist, personal communication).

\begin{abstract}
Magnusson and the $B O$ do a great job but seek independence from the municipality which hampers the extension of the biosphere concept from the presentfocus on nature conservation and ecotourism to broader infrastructure issues like the built environment. Politicians are still passive spectators and view KVBR more like a decoration than a model for ecodevelopment. In relation to the municipal administrations the $B O$ sometimes acts like an orderer (Dahlman, personal communication).
\end{abstract}

The second column of Table 1 indicates whether the organization has legal authority to make and enforce laws and regulations concerning land use in Kristianstad. These formal institutions exist at multiple organizational levels and are often referred to as polycentric institutions (Ostrom 1998, McGinnis 2000). However, it is interesting to note that several of the main actors, including the BO and the multilevel MAB institutions, lack legal mandate and enforcement power. Polycentric formal institutions have been important enabling structures, which the BO has successfully navigated with support from the interviewed key persons at these institutions. But the commitment by key persons representing various NGOs with no legal power (MAB, universities, WWF, and the farmers' organization) has also been necessary for this governance network.

KVBR has often been referred to as only loosely nested in the formal democratic structure, which has given the BO unusual freedom (Olsson et al. 2004, Hahn et al. 2006). The interviews reveal that the governance network is loosely nested in the representative democratic system only when it comes to how it operates, how initiatives are taken, and how different actors collaborate. It seems completely embedded/nested when it comes to how decisions are finally taken. Hence, the BO has combined enthusiasm and entrepreneurship with an ability to navigate the political system (Hellmo, personal communication). Rather than feeling threatened by the informal governance of KVBR, the former social democratic and the present conservative chairs of the MEB both claim they have become inspired by the $\mathrm{BO}$ :

I have realized the importance of informal arenas for learning and creativity. These processes have yielded other effects, e.g., we are about to become a fossil-free municipality. Inspired by the $\mathrm{BO}$, the municipality invites farmers to "Environmental breakfasts" where we discuss environmental impacts of agriculture. Today we have a different dialogue about environmental concerns (Kristiansson, former Chair of the MEB). 
We are an environmental friendly town with official cars and buses driven by biogas, so the biosphere reserve fits with our profile. The present conservative rule makes no difference in this respect. The MEB is fully accountable for the development of the biosphere reserve, we are not spectators to a higher degree than for any other issue. There are many interest groups involved in governance but ultimately it's the MEB that makes the decisions (Gustafson, present chair of the MEB).

Gunnar Zettersten, formerly at SEPA, learned about MAB when he represented SEPA in the European Council. Being aware of the limitations of the major tools for nature conservation (national parks and nature reserves), he was attracted by the ideas behind MAB and became a member of the new Swedish MAB Committee in 1998. Regarding the informality of the KVBR governance network, compared with traditional conservation work, he explains:

When working with MAB issues I first try to meet the persons who are involved in a nature conservation issue; as second-best I call them. Only after talking about the issue I do the compulsory paper work and write letters and so on.

In KVBR, nature conservation is not driven by legislation; legislation (nature reserves and other regulations) is only used as a final step to consolidate or "formalize" the results of informal collaboration (Hahn et al. 2008). In Magnusson's words: "I never refer to legislation in my initial contacts with farmers, that's like waving with a red flag."

Of all interviewees, only two-Mattiasson at the CAB and Dahlman at the Municipal Technical Administration-expressed concern that politicians are not sufficiently in charge of the planning of KVBR and hence not accountable or committed if the process would encounter problems. They emphasized that the present structure is democratic but anticipated larger challenges now when the biosphere reserve is growing in activities and budget. They are both afraid that the independence sought by the BO may become a problem in the long run.

The $\mathrm{BO}$ is an independent actor but completely dependent on political support from the $M E B$ and the $C A B$. Without the support from the $C A B$ it would not have succeeded. Now when it is a biosphere reserve the politicians need to "own" the process to be more accountable, the $\mathrm{BO}$ cannot remain in charge of everything (Mattiasson, personal communication).

A good signal, however, Mattiasson noted, is that the MEB is directly in charge of the process of and large investment in Naturum, which opens in November 2010 as the center of the biosphere reserve with exhibitions, conferences, nature school, and a restaurant. I asked four personsMagnusson at the BO, Gustafson at the MEB, Bergqvist at the SEPA, and Löfroth at the WWFwho are accountable if this big Naturum project would fail (in WWF's case, other projects they have financed). They all accepted accountability if this would happen: Magnusson for the proposal, Gustafson for the decision, and the others for their respective financial contributions.

\section{NATURUM IN A PANARCHY CONTEXT}

Analyzing social change requires understanding of processes at several levels of social organization (Cash et al. 2006). Higher levels (e.g., constitutional rules) change slower and constrain and direct the faster dynamics at lower levels (e.g., operational rules). Emphasizing that all levels in a hierarchy are dynamic and undergo four phases (birth/growth, maturation, death/release, and renewal/reorganization), Holling and others (2002) use the terms adaptive cycle and panarchy. The four phases represent the adaptive cycle, and a nested set of adaptive cycles across space and time scales represents a panarchy. Dynamics at a lower level may revolt and push the higher level from a mature and rigid phase into a release phase. Or the stability at the higher level may serve as a memory to facilitate and direct reorganization at a lower level after a crisis.

The latter can be illustrated by Naturum in evaluation of the adaptive capacity of KVBR. Before 2007, the local investments in KVBR paid by the MEB had been very limited thanks to an extremely efficient project organization and financial support from several governmental organizations and NGOs (Hahn et al. 2006). However, Naturum pulled down KVBR at the MEB level to the Omega phase of crisis in 2007-2009 (see Fig. 2). The former chair of MEB, Bo 
Kristiansson, referred to this time of handling the cost-escalation as the biggest crisis of KVBR. Indeed, the large investment in Naturum can be seen as an accountability test, since the political turmoil within the MEB forced the politicians to reveal their commitment. Naturum is funded by the municipality but with a uniquely large contribution by SEPA, 16 MSEK, and some smaller contributions to the operational costs by the SEPA/ $\mathrm{CAB}$ and Region Scania. The reason is that the SEPA was "deeply impressed by the work in Kristianstad, the holistic and collaborative approach to nature conservation is a Swedish role model."[3]

In August 2007, the MEB reserved 50 MSEK to Naturum, but only a few months later the budget was announced to be 100 MSEK, due to construction difficulties and new connecting bridges. This put a tremendous pressure on the MEB. Gustafson, the MEB Chair, said this was unacceptable and argued that the costs must be reduced and the focus changed from being "an isolated nature conservation interest." The project manager added that "either we build Naturum or we don't". ${ }^{[4]}$ Reducing Naturum/KVBR to an "isolated nature conservation interest" was a signal that the legitimacy was questioned, and thereby politicians were reluctant to accept accountability.

This crisis was apparently solved in February 2008 when the project was modified and the budget cut to 75 MSEK (91 MSEK including SEPA's contribution). Magnusson's idea to have his BO office inside Naturum was compromised (Lövkvist, personal communication). Drawing on the higherlevel governance network, Gustafson argued that SEPA's contribution was contingent on keeping the time plan. ${ }^{[5]}$ The top politicians from all eight parties were satisfied, and the project planning could continue.

However, the consensus was only apparent. The local conservative alliance inherited the project from the social democrats who had been in power 1988-1991 and 1994-2006. Several politicians from the five parties in the conservative alliance had little commitment to the biosphere reserve, and when the bankruptcy of Lehman Brothers in September 2008 catalyzed the global financial crisis, these politicians voiced their opinion. In March 2009, the second top conservative politician, Bidsell, publicly attacked Gustafson, the Chair. The financial crisis had motivated closing a public school, and "when we have to cut everywhere you
[Gustafson] plan for a new investment of 90 MSEK and new annual costs of 7 MSEK. Your crystal ball [vision for the future] is filled with muddy water from the swamp." $[6]$

Bidsell claimed he had wide support for his opinion within the conservative alliance. The political opposition, led by Fritzon, responded by reminding the conservative alliance about the uniqueness of being a UNESCO biosphere reserve and the support from the Swedish government, SEPA, the CAB, and Region Scania. "It's an insult to all international work for a climate smart and sustainable society to call KVBR a swamp." ${ }^{[7]}$ Being a biosphere reserve has become an identity for Kristianstad, and "this is not like a diploma but an obligation that we need to live up to," Fritzon argued (personal communication).

In April 2009, the local parliament voted to go ahead with Naturum, 56 votes for and 9 against. ${ }^{[8]}$ Hence, the politicians accepted accountability also in times of a crisis motivated by increasing budgeted costs and fueled by an external financial shock (Fig. 2). The findings from the interviews suggest that the social capacity among top politicians, civil servants, and NGOs - the organizational ability to create and develop a biosphere reserve including intellectual, financial, and moral/political support-served as a memory for the MEB when navigating the turbulent times of cost escalation and political resistance. This social memory consisting of crucial vertical links showed to be useful, probably essential, for adapting the decision process and thus enhancing resilience of the biosphere trajectory in times of an external financial driver. The two stormy times in November 2007 and March 2009 were tipping points during which a few individuals made the difference (Magnusson, personal communication).

Without the social memory and support from the governance network, a considerable investment like Naturum would probably be hard to imagine. In Magnusson's words: "Had we presented these plans 16 years ago [when we first envisioned Naturum] people would think we were out in the blue." ${ }^{[9]}$ A similar reflection was made by the Head of Land and Exploitation Office:

The biosphere office (BO) was placed directly under the MEB Chair which was very unusual and gave the whole project an informal character. I think this made the project more vulnerable when the Naturum budget doubled in 2008. But at the same 
Fig. 2. Two levels of the governance panarchy of KVBR concerning the dynamics around Naturum. The front loop, $r$ to $K$, was driven in 1988-2006 by actors at both local and district/national levels. The MEB responded by making the appropriate decisions. In 2007-2009, two crises (internal project budget and externally imposed financial) pulled the biosphere development at the MEB level into the release $(\Omega)$ and renewal $(\alpha)$ phases (the back loop), whereas the governance network at higher levels remained in the conservation phase $(K)$. The social memory at these higher levels-illustrated by the financial, intellectual, and moral-political support mainly from the SEPA, Unesco MAB, the CAB, and Region Scania-influenced the MEB to continue developing the biosphere reserve. The ruling conservative party reorganized accordingly.

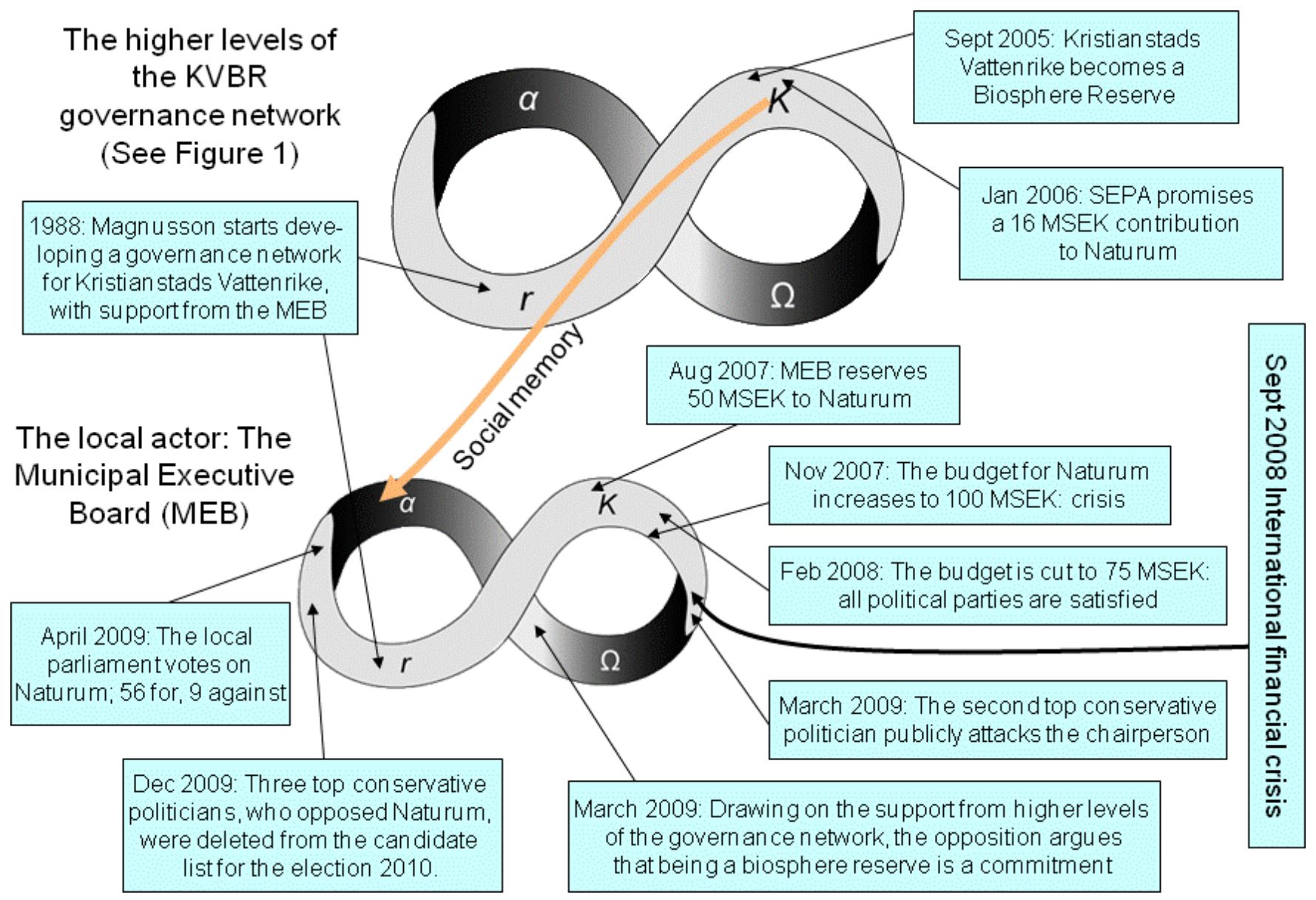

time the legitimacy was growing all the time and the external money to Naturum enhanced the stability. Magnusson has managed to get support from the MEB for his vision for KVBR thanks to his large network (Lövkvist, personal communication).

The Naturum process caused a major crisis in the ruling conservative party, and the backloop $(\Omega$ and $\alpha$ phases) ended in December 2009 when three top conservative politicians, who had opposed Naturum, were deleted from the candidate list for the 2010 election, probably by Gustafson. ${ }^{[10]}$ When Naturum opened in November 2010, KVBR started a new growth $(r)$ phase at the MEB level, following the same trajectory as the first adaptive cycle with the difference that KVBR has changed, at least temporarily, from "low politics" to higher political and economic stakes and with a clear accountability and ownership by the MEB. This provides stability, 
but the question is whether this will result in a marginalization of the governance network, and if so, would this impede adaptability? I will soon return to this.

\section{ANALYSIS: SHARED ACCOUNTABILITY THROUGH NESTEDNESS}

To analyze the multilevel governance network and its constitutional status, including effects on accountability, I use the four conjectures, or hypotheses, suggested by Klijn and Skelcher (2007). In Table 2, accountability is constructed outside representative democracy only in the transitional hypothesis, by securing openness and transparency of decision made within the governance network. The transitional and complementarity hypotheses share an emphasis on social learning and deliberation, with the difference that the latter only complements representative democracy and thus results in a shared accountability: politicians devolve issues of low politics to governance networks. The incompatible and instrumental hypotheses share the classical view that accountability lies with elected politicians only; in the former, governance networks threaten accountability, whereas in the latter, politicians may use performance indicators to control other actors. The instrumental and complementarity hypotheses are both nested in the representative democratic system, but whereas the instrumental thesis is limited to a pragmatic concern about outcomes and service delivery, the complementary thesis emphasizes both input (policy formulation) and output (implementation) legitimacy (Klijn and Skelcher 2007).

These four hypotheses reflect a broad definition of governance networks. In a review by Ansell and Gash (2007), it is argued that policy/governance networks refer to similar phenomena as "collaborative governance" with the difference that the former often describes informal and implicit cooperation, and the latter typically refers to "an explicit and formal strategy of incorporating stakeholders into multilateral and consensusoriented decision-making processes" (pp. 5-6). Following this, the concepts policy/governance networks should be limited to the complementarity hypothesis, whereas collaborative governance is more related to the instrumental and transitional hypotheses.
None of the interviewees perceived the BO or its governance network as a "parallel democracy," neither as alternative (Hypothesis B) or as threat (Hypothesis A) to representative democracy. On the contrary, all respondents described it as transparent and nested in formal structures. Fritzon, the previous chair of the MEB believes the following:

\section{All means of public participation actually strengthen the representative democracy. The local parliament now allows citizens to write proposals, this is enabled by the new legislation. However, as social democrat I am concerned that this mostly benefits the well-educated middle-class, the participation is not as vivid in the poorer neighbourhoods.}

The governance network around the BO can most accurately be assessed using the complementarity hypothesis. Until 2007, it dealt mainly with issues that Klijn and Skelcher (2007) call low politics: the stakes were not perceived to be very high, and before Naturum, most people saw KVBR as a nice biodiversity and eco-tourism project (Hahn et al. 2006).

Magnusson's strategy has been to build trust and consensus around win-win projects and increase the stakes when legitimacy gained by previous achievements allowed for that. In other words, legitimacy has been the bridge between adaptability and accountability; politicians accept accountability as long as they perceive the adaptive navigation and performance by the governance network as legitimate.

The instrumental hypothesis cannot explain the origin of KVBR, although some of the interviewees envision a greater role for the MEB and perhaps the $\mathrm{CAB}$ to use Naturum and parts of the governance network, especially the Consultancy Group, to enhance their own political objectives more strategically and efficiently, rather than just waiting for initiatives from the $\mathrm{BO}$ and its governance network.

Previously, ideas, knowledge, and strategies for how to develop KVBR have been created through informal contacts within the governance network; learning thrives in informal settings (Westley 1995). Based on this and meetings in the Consultancy Group for nature conservation, the BO has made proposals that the MEB and local parliament have accepted, usually with little modifications 
Table 2. Four governance network hypotheses in relation to KVBR

\author{
Governance network hypotheses (in relation to $\quad$ Relevance for KVBR \\ representative democracy)
}

A. The incompatibility hypothesis: Describes governance network as closed cooperation between strong vested interests forming iron triangles. The bridging or "interbonding" links between these organizations exclude other stakeholders and threaten the public interest.

B. The transitional hypothesis: Argues that representative democracy will be replaced by governance networks. Decisions will increasingly be made through stakeholder deliberation, reducing the role of politicians to facilitators. The "public interest" is constructed during the process.

C. The instrumental hypothesis: Regards governance networks as a means for strong governmental actors to accomplish their objectives. An example could be the 33 River Rehabilitation Councils around Lake Laguna in the Philippines in which stakeholders meet and solve conflicts under the supervision and power of the state (Folke et al. 2005:461)

D. The complementarity hypothesis: Describe governance networks as quasi-governmental networks with loosely defined constitutional status in which civil society can interact with public servants. The network is involved in policy formulation and not just implementation as in the instrumental hypothesis.
Not relevant. For the local steward networks, it is true that the BO often selects partners strategically for voluntary collaboration (theme and adhocracy groups). But these are no collective-choice issues. The consultancy group and the governance network are transparent.

Not relevant. The governance network is not replacing representative democracy. The municipality has been inspired by the BO, but there is no sign of transition. The conflict on Naturum moved KVBR to "high politics," and the MEB took more control of the process, contrary to a transition.

Potentially relevant. This hypothesis describes a top-down approach by government agencies to strengthen their effectiveness. KVBR is a bottom-up initiative. The consultancy group, however, may in the future be more formalized and, together with Naturum, used more strategically by the MEB and the CAB to further their objectives concerning nature conservation and the biosphere reserve.

Highly relevant, at least until 2007. The BO has been directly under the MEB Chair, but its governance network was only loosely nested to the MEB and the CAB. This enables public servants to interact across agencies and with civil society. After Naturum, the MEB may choose to control the biosphere development or continue relying on initiatives from the governance network.
(Kristiansson, personal communication). With Naturum, this has changed and the MEB has taken more control of the development, reflecting a higher degree of accountability. Now there may be a bifurcation point; either the MEB turns KVBR into an ordinary municipal project where the MEB initiates new policy goals using the $\mathrm{BO}$ and its governance network for implementation (instrumental hypothesis), or the MEB regards the large investment in Naturum as a unique event, requiring more steering, and after this returns to the "old" routines of giving the $\mathrm{BO}$ and its governance network a high degree of freedom to propose how to continue developing and adapting KVBR to new internal and external challenges (complementarity hypothesis). The latter would be more in line with the ecosystem approach ${ }^{[11]}$ and also the theory of adaptive governance (Folke et al. 2005). However, this is not to say that the instrumental hypothesis, e.g., using KVBR as a model for a broader ecodevelopment as envisioned by Dahlman, would be worse from a normative/sustainability point of view. As suggested by the Millennium Ecosystem Assessment (2005:72), several scenarios may promote a sustainable development, not only the "Adapting Mosaic" Scenario (which resembles adaptive governance).

One sign of change to the instrumental hypothesis could be the reorganization of the BO in June 2009, from being directly under the MEB Chair to becoming a part of the Municipal Coordination Administration. Magnusson (personal communication) had resisted this organizational change for several years but finally gave in to reduce the political turmoil around Naturum. In his view, however, the $\mathrm{BO}$ has been able to continue its flexible approach with extensive networking and trust building; there 
are no other signals from the politicians. There were only some initial conflicts with the civil servants when he resisted becoming part of an "inefficient meeting culture." Now, the head of the Coordination Administration assures that there are no restrictions in flexibility and the BO still has a free mandate to network (Persson, personal communication). A tentative conclusion is that, so far, the increase in stakes and accountability by the representative democracy has not reduced flexibility, adaptability, or the role of the governance network.

\section{DISCUSSION}

The highly empirical approach taken here has shed light on accountability issues related to a governance network of a biosphere reserve. In relation to the first two research questions, it was found that the self-organized governance network is nested in the formal democratic system and, as a result, there is a complementarity and shared accountability between the network and representative democracy.

In the governance network of KVBR, there are several key persons representing various agencies and NGOs who are highly committed to the project, and all accept accountability if their respective financial contributions and/or proposals would result in a failure. However, except for the BO, this is more related to internal accountability vis-à-vis their respective organization/agency (Stoker 1998) because a failure (e.g., due to advice from the WWF) would mainly result in decreased influence on the MEB. The MEB, together with the BO, would still be held accountable vis-à-vis the local inhabitants because the leadership exerted by the BO cannot be reduced to the role of a lobbyist.

What are the lessons learned from KVBR, and what may be generalized? First, insofar as issues of ecosystem-based management and biosphere reserves are considered to be low politics, we may expect to find governance networks nested in representative democracy either with a shared accountability (engaged in policy formulation) or used by politicians in a more instrumental way (only implementation). In situations like KVBR, in which governance networks have a profound impact on decision making, Klijn and Skelcher (2007) argue that it is not reasonable to allocate accountability only to the elected assemblies that formally make the final decisions; the key persons who have contributed with their knowledge and strategies, and their organizations, should be acknowledged as coowners of the process with a shared accountability of the outcomes. In a similar vein, Scott (2000) has referred to this as "extended accountability," arguing that it is usually a consequence of the fragmentation of the public sector, making "more transparent the existing dense networks of accountability associated with both public and private actors concerned with the delivery of public services" (p. 40). In KVBR, the BO, and Magnusson in particular, clearly has a shared accountability, whereas the other actors arguably have a more internal or "nested" accountability.

Second, the relationship between the governance network and the government network of civil servants seems to be contingent on both leadership and type of issues. Embedding the proposals and work by an innovative, flexible, and open network of concerned individuals into the municipal and institutional structures was a strategy chosen by Magnusson right from the start in 1989. This has gained wide praise and support, lately from the Swedish environmental minister, ${ }^{[12]}$ which of course reinforces the resilience (or path dependency) of this trajectory. One possible explanation to the chosen path is that both Magnusson and Cronert were civil servants, hence used to anchoring their ideas within the political system. However, experiences from the Netherlands suggest that leadership by civil servants is no guarantee for embeddedness if the issues are controversial. Huitema and Meijerink (2010) report from 17 cases of water transitions in the Netherlands that several officials working on radical ("high politics") alternative approaches to water management had to do so "with only silent support from their superiors and eventually had to take jobs outside the bureaucracy. A 'shadow position' achieved in this way gives them a greater flexibility in advancing their ideas" (Huitema and Meijerink 2010:376). The advantage of informal shadow network, out of the fray of regulation and implementation, for exploring innovative and adaptive approaches to ecosystem management has also been emphasized by Gunderson (1999).

The KVBR governance network has been referred to as a shadow network by Olsson et al. (2006), but at the same time it has been transparent and enjoyed legitimacy. If shadow networks are contrasted with "legitimate networks" (Shaw 1997), then the KVBR governance network is both. Most respondents saw 
their engagement in KVBR as part of their job, although some key persons (Magnusson, Cronert, Olsson, Löfroth, and Folke) had definitely created their own mandates. The fact that the decisionmaking power concerning KVBR has been fully embedded in the democratic structure from the start may explain why accountability has not been a significant problem. Otherwise, the literature is full of cases in which the scale of ecosystems management does not match the scale of power and accountability; very often local initiatives are good at developing local networks and generating action but fail to embed this into the political power structures. The Sub-global Millennium Ecosystem Assessment identified this lack of embeddedness and lack of multilevel collaboration as a major characteristic of unsuccessful responses to ecosystem change (Malayang et al. 2006).

Third, what can this case tell us about resilience and adaptability, which are supposed to be enhanced by governance network? The handling of the political turmoil around Naturum suggests that the adaptive capacity of the multilevel governance network was decisive for protecting the Naturum project and hence the resilience of the whole biosphere trajectory. Folke et al. (2010) propose that adaptation and even transformation at lower scales (in this case, the MEB) may be necessary for resilience at higher scales (the whole biosphere network).

Plummer and Armitage (2007:65) suggest that the outcomes of adaptive co-management processes may be evaluated using a broad spectrum of parameters that are forward-looking and highlight cross-scale influences. First-order parameters are those that can be assessed within the project frame (e.g., flexibly live with uncertainty and deal with cross-scale dynamics, creativity, and legitimacy for policy change), whereas second order (outside boundaries of project) and third order (evident subsequently) parameters include changes in perceptions and actions, extended engagement and learning across scales, and "creating opportunities for self-organization that match ecosystem and governance scales and anticipate external drivers" (p. 71).

Certainly, adaptive responses to sustain resilience are facilitated if the scale of governance can match the scale of drivers, referred to as spatial fit by Galaz et al. (2008). The process following the global financial crisis suggests that the adaptability of
KVBR is high. However, recent ecological threats, such as brownification and decline in some bird populations, call for configurations to remain adaptive. For brownification, a catchment approach is needed. The present governance network has not succeeded in involving actors in upstream municipalities. Either a shadow network needs to emerge to include these actors or the institutional opportunities offered by the European Water Directive Framework needs to be realized (M. Tuvendal and T. Elmqvist, unpublished manuscript).

Reversing the decline of bird populations requires international cooperation, maybe European investments in African winter habitats and European migration corridors and stepping stones. Adaptive governance at European-African level may be facilitated through the MAB community (Cronert, personal communication) or The Ramsar Convention and The European Commission Communication on the Wise Use and Conservation of Wetlands (Amezaga 2002). A sense of shared or extended accountability, involving agencies and NGOs at several organizational levels, probably needs to develop for addressing these challenges and providing the necessary knowledge and leadership.

\section{CONCLUSIONS}

The governance network of KVBR is loosely nested in the representative democratic system only when it comes to how it operates, how initiatives are taken, and how different actors collaborate. This informality enhances flexibility and adaptability. However, the governance network is fully embedded/nested when it comes to how decisions are finally taken, ensuring traditional accountability vis-à-vis citizens. Hence, the governance network complements representative democracy: some key persons of the governance network and the agencies and NGOs they represent are co-owners of the decision process that creates a sense of shared or extended accountability. This design appears to facilitate adaptive governance.

The tension between accountability and adaptability will exacerbate when the demand for ecosystem services increases (become "high politics") and when new adaptive and collaborative approaches are called for, for example, when the spatial scale of governance increases. The BO has approached this tension constructively by starting with small 
win-win projects and gradually increasing the stakes and spatial scale, when legitimacy gained by previous achievements allowed for that. Legitimacy, trust, and transparency have bridged adaptability with accountability, and this may explain why politicians finally accepted accountability for Naturum.

The intellectual, financial, institutional, and moral/ political support by the higher levels of the governance network have been vital for guiding local politicians along the biosphere trajectory. Naturum moved KVBR temporarily from low politics to high politics. There are signs of giving the $\mathrm{BO}$ and its governance network a more instrumental role focusing on implementation only, which would limit its independence and adaptability, but the analysis suggests that its responsibility for innovative policy formulation persists.

Responses to this article can be read online at: http://www.ecologyandsociety.org/voll6/iss2/art18/ responses/

\section{Acknowledgments:}

I want to thank Andreas Duit, who several years ago asked the critical questions that provoked me to write this article. I also want to thank all respondents for sharing your valuable time. Comments by Björn Nykvist and three anonymous reviewers were very helpful. This research was financed by The Swedish Research Council for Environment, Agricultural Sciences and Spatial Planning (Formas). The research is supported by Mistra through a core grant to the Stockholm Resilience Centre, a cross-faculty research center at Stockholm University.

\section{LITERATURE CITED}

Amezaga, J., L. Santamaria, and A. Green. 2002. Biotic wetland connectivity: supporting a new approach for wetland policy. Acta Oecologica 23:213-222.

Ansell, C., and A. Gash. 2007. Collaborative governance in theory and practice. Journal of Public Administration Research and Theory 18(4):543-571.
Barthel S., C. Folke, and J. Colding. 2010. Socialecological memory in urban gardens: retaining the capacity for management of ecosystem services. Global Environmental Change 20:255-265.

Berkes, F., J. Colding, and C. Folke, editors. 2003. Navigating social-ecological systems: building resilience for complexity and change. Cambridge University Press, Cambridge, UK.

Biermann, F. 2007. "Earth system governance" as a crosscutting theme of global change research. Global Environmental Change 17(3-4):326-337.

Biernacki, P., and D. Waldorf. 1981. Snowball sampling: problems and techniques of chain referral sampling. Sociological Methods Research 10:141-163.

Cash, D. W., W. N. Adger, F. Berkes, P. Garden, L. Lebel, P. Olsson, L. Pritchard, and O. Young. 2006. Scale and cross-scale dynamics: governance and information in a multilevel world. Ecology and Society 11(2): 8. [online] URL: http://www.ecology andsociety.org/vol11/iss2/art8/.

Folke, C., S. Carpenter, T. Elmqvist, L. Gunderson, C. S. Holling, and B. Walker. 2002. Resilience and sustainable development: building adaptive capacity in a world of transformations. Ambio 31 (5):437-440.

Folke, C., S. Carpenter, B. Walker, M. Scheffer, T. Chapin, and J. Rockström. 2010. Resilience thinking: integrating resilience, adaptability and transformability. Ecology and Society 15(4): 20. [online] URL: http://www.ecologyandsociety.org/vol15/ iss4/art20/.

Folke, C., T. Hahn, P. Olsson, and J. Norberg. 2005. Adaptive governance of social-ecological systems. Annual Review Environment and Resources 30:441-473.

Galaz, V., P. Olsson, T. Hahn, C. Folke, and U. Svedin. 2008. The problem of fit among biophysical systems, environmental and resource regimes, and broader governance systems: insights and emerging challenges. Pages 147-186 in O. R. Young, et al., editors. Institutions and environmental change: principal findings, applications, and research frontiers. The MIT Press, Cambridge, Massachusetts, USA.

Gulbrandsen, L. H. 2004. Overlapping public and private governance: can forest certification fill the 
gaps in the global forest regime? Global Environmental Politics 4(2):75-99.

Gunderson, L. H. 1999. Resilience, flexibility and adaptive management: antidotes for spurious certitude? Conservation Ecology 3(1): 7. [online] URL: http://www.consecol.org/vol3/iss 1/art7/.

Hahn, T., P. Olsson, C. Folke, and K. Johansson. 2006. Trust-building, knowledge generation and organizational innovations: the role of a bridging organization for adaptive co-management of a wetland landscape around Kristianstad, Sweden. Human Ecology 34(4):573-592.

Hahn, T., L. Schultz, C. Folke, and P. Olsson. 2008. Social networks as sources of resilience in socialecological systems. Pages 119-148 in J. Norberg and G. Cumming, editors. Complexity theory for a sustainable future. Columbia University Press, New York, New York, USA.

Hajer, M., and H. Wagenaar. 2003. Deliberate policy analysis: understanding governance in the network society. Cambridge University Press, Cambridge, UK.

Holling, C. S., L. H. Gunderson, and G. D. Peterson. 2002. Sustainability and panarchies. Pages 63-102 in L. H. Gunderson and C. S. Holling, editors. Panarchy: understanding transformations in human and natural systems. Island Press, Washington, D.C., USA.

Holling, C. S., and G. K. Meffe. 1996. Command and control and the pathology of natural resource management. Conservation Biology 10:328-337.

Hooghe, L., and G. Marks. 2003. Unraveling the central state, but how? Types of multi-level governance. American Political Science Review 97 (2):233-243.

Huitema, D., and S. Meijerink. 2010. Policy dynamics in Dutch water management: analysing the contribution of policy entrepreneurs to policy change. Pages 349-368 in D. Huitema and S. Meijerink, editors. Water policy entrepreneurs: a research companion to water transitions around the globe. Edward Elgar Publishing, Cheltenham, UK.

Imperial, M. T. 2005. Using collaboration as a governance strategy: lessons from six watershed management programs. Administration and Society 30:281-320.
Kettl, D. F. 2000. The transformation of governance: globalization, devolution, and the role of government. Public Administration Review 60:488-497.

Klijn, E-H., and C. Skelcher. 2007. Democracy and governance networks: compatible or not? Public Administration 85(3):587-608.

Kvale, S. 1996. Interviews: an introduction to qualitative research interviewing. SAGE Publications, Thousand Oaks, California, USA.

Lebel, L., J. M. Anderies, B. Cambell, C. Folke, S. Hatfield-Dodds, T. P. Hughes, and J. Wilson. 2006. Governance and the capacity to manage resilience in regional social-ecological systems. Ecology and Society 11(1): 19. [online] URL: http://www.ecolog yandsociety.org/vol11/iss11/art19/.

Lowndes, V. 2001. Rescuing Aunt Sally: taking institutional theory seriously in urban politics. Urban Studies 38(11):1953-1971.

Malayang, B. S., T. Hahn, and P. Kumar. 2006. Chapter 9: Responses to ecosystem changes and their impacts on human well-being: lessons from sub-global assessments. Pages 203-226 in D. Capistrano, C. Samper K., and C. RaudseppHearne, editors. Ecosystems and human well-being: multiscale assessments, volume 4. Island Press, Washington, D.C., USA. [online] URL: http://maw eb.org/documents/document.347.aspx.pdf.

Mason, M. 2005. The new accountability: environmental responsibility across borders. Earthscan, Toronto, Canada.

McGinnis, M. 2000. Polycentric governance and development. University of Michigan Press, Ann Arbon, Michigan, USA.

Millennium Ecosystem Assessment. 2005. Ecosystems and human well-being: synthesis. Island Press, Washington, D.C., USA. [online] URL: http://maw eb.org/documents/document.356.aspx.pdf.

Mintzberg, H. 1979. The structuring of organizations: a synthesis of the research. PrenticeHall, Englewood Cliffs, New Jersey, USA.

Olsson, P., C. Folke, V. Galaz, T. Hahn, and L. Schultz. 2007. Enhancing the fit through adaptive comanagement: creating and maintaining bridging 
functions for matching scales in the Kristianstads Vattenrike Biosphere Reserve Sweden. Ecology and Society 12(1): 28. [online] URL: http://www.e cologyandsociety.org/vol12/iss 1/art28/.

Olsson, P., C. Folke, and T. Hahn. 2004. Socialecological transformation for ecosystem management: the development of adaptive co-management of a wetland landscape in southern Sweden. Ecology and Society 9(4): 2. (Online) URL: http://www.eco logyandsociety.org/vol9/iss4/art2/print.pdf.

Olsson P., L. Gunderson, S. R. Carpenter, P. Ryan, L. Lebel, C. Folke, and C. S. Holling. 2006. Shooting the rapids: navigating transitions to adaptive governance of social-ecological systems. Ecology and Society 11(1): 18. [online] URL: http: //www.ecologyandsociety.org/vol11/iss1/art18/.

Ostrom, E. 1998. Scales, polycentricity, and incentives: designing complexity to govern complexity. Pages 149-167 in L. D. Guruswamy and J. A. McNeely, editors. Protection of global biodiversity: converging strategies. Duke University Press, Durham, North Carolina, USA.

Pahl-Wostl, C., M. Craps, A. Dewulf, E. Mostert, D. Tabara, and T. Taillieu. 2007. Social learning and water resources management. Ecology and Society 12(2): 5. [online] URL: http://www.ecology andsociety.org/vol12/iss2/art5/.

Plummer, R., and D. Armitage. 2007. A resiliencebased framework for evaluating adaptive comanagement: linking ecology, economics and society in a complex world. Ecological Economics 61:62-74.

Pretty, J. 2003. Social capital and the collective management of resources. Science 302:1912-1914.

Scheffer, M., F. Westley, and W. Brock. 2003. Slow response of societies to new problems: causes and costs. Ecosystems 6:493-502.

Schultz, L., C. Folke, and P. Olsson. 2007. Enhancing ecosystem management through socialecological inventories: lessons from Kristianstads Vattenrike, Sweden. Environmental Conservation 34(2):140-152.

Schusler, T. M., D. J. Decker, and M. J. Pfeffer. 2003. Social learning for collaborative natural resource management. Society and Natural Resources 15:309-326.
Scott, C. 2000. Accountability in the regulatory state. Journal of Law and Society 27(1):38-60.

Shaw, P. 1997. Intervening in the shadow systems of organizations. Journal of Organizational Change Management 10(3):235-250.

Steel, B. S., and E. Weber. 2001. Ecosystem management, decentralization, and public opinion. Global Environmental Change 11:119-131.

Stoker, G. 1998. Governance as theory: five propositions. International Social Science Journal 50(155):17-28.

Tippett, J., B. Searle, C. Pahl-Wostl, and Y. Rees. 2005. Social learning in public participation in river basin management: early findings from HarmoniCOP European case studies. Environmental Science \& Policy 8(3):287-299.

Westley, F. 1995. Governing design: the management of social systems and ecosystems management. Pages 391-427 in L. H. Gunderson, C. S. Holling, and S. Light, editors. Barriers and bridges to the renewal of ecosystems and institutions. Columbia University Press, New York, New York, USA.

Young, O. 2002. The institutional dimensions of environmental change: fit, interplay and scale. Cambridge University Press, Cambridge, UK.

\section{Personal communications:}

Åkesson, Hans. Chair Farmers Federation Kristianstad.

Axelsson, Christine. Region Scania, Development and Growth Fund.

Bergqvist, Anders, Swedish Environmental Protection Agency (SEPA).

Cronert, Hans. County administrative board.

Dahlman, Michael. Municipal Technical Administration.

Dogsé, Peter. Unesco International Man and Biosphere office.

Folke, Carl. Stockholm University. 
Fransman, Bo. Region Scania, Environmental Fund.

Fritzon, Helene. Chair municipal executive board (s).

Gustafson, Bengt. Chair municipal executive board (m).

Hellmo, Elisabeth. County administrative board.

Kristiansson, Bo. Chair municipal executive board (s).

Larsson, Torsten. Swedish Environmental Protection Agency (SEPA).

Löfroth, Michael. WWF, Program leader wetlands.

Lövkvist, Ingvar. Land and Exploitation office.

Mattiasson, Göran. County administrative board.

Magntorn, Karin. Head of information of the Biosphere Office.

Magnusson, Sven-Erik. Director of the Biosphere Office.

Olsson, Olof. MAB Office and Mistra.

Persson, Göran. Head of the Municipal Coordination Administration.

Theander, Tomas. City Architect at the municipal administration.

Thelaus, Magnus. Kristianstad University College.

Zettersten, Gunnar. Swedish Environmental Protection Agency (SEPA).

[1] Governance networks are more or less similar to "policy networks." Both terms are concerned with policy outcomes, but scholars using the term governance networks usually emphasize legitimacy and accountability concerns in the interaction process (Klijn and Skelcher 2007:595). Another related concept, "network governance," is defined by the same authors as "a particular mode of societal organization, which is usually contrasted with market and hierarchy (Klijn and Skelcher 2007:587).
${ }^{[2]}$ http://www.kristianstadsbladet.se/incoming/ article822665/Vattenriket-fick-naturvaringrdspris.html

${ }^{[3]}$ http://www.kristianstadsbladet.se/kristianstad/ article1070305/Ett-foumlredoumlme-foumlr-svensknaturvaringrd.html

${ }^{[4]}$ http://www.kristianstadsbladet.se/kristianstad/ article1064721/Foumlrdubblat-pris-foumlr-Naturum. $\underline{\mathrm{html}}$

${ }^{[5]}$ http://www.kristianstadsbladet.se/kristianstad/ article929277/Klartecken-foumlr-Naturum.html

${ }^{[6]}$ http://www.kristianstadsbladet.se/kristianstad/ article937255/Toppmoderat-garingr-till-haringrtBRangrepp-mot-Gustafson.html

[7]http://www.kristianstadsbladet.se/fria-ord/article926036/ Dags-att-de-fem-tar-ansvar.html

${ }^{[8]}$ http://www.kristianstadsbladet.se/kristianstad/ article929277/Klartecken-foumlr-Naturum.html

${ }^{[9]}$ http://www.kristianstadsbladet.se/kristianstad/ article1070305/Ett-foumlredoumlme-foumlr-svensknaturvaringrd.html

${ }^{[10]}$ http://www.kristianstadsbladet.se/kristianstad/ article943611/Politiker-petas-fraringn-fullmaumlktigelista. $\underline{\mathrm{html}}$

${ }^{[11]}$ The ecosystem approach or the Malawi principles are internationally agreed standards from 1998; they consist of 12 principles of ecosystem management: http://www.cbd.int/ecosystem/principles. $\underline{\text { shtml }}$

${ }^{[12]}$ http://www.kristianstadsbladet.se/kristianstad/ article884619/Ministern-i-Vattenriket.html 